\title{
Developmental Ideology and Banality of Environmental Evil in the Republican History of Brazil: From the Ferrovia do Diabo to the Rodovia Transamazônica
}

\author{
Ideologia Desenvolvimentista e Banalidade do Mal Ambiental na História Republicana do \\ Brasil: Da Ferrovia do Diabo à Rodovia Transamazônica
}

\author{
Carlos Renato Carola ${ }^{1}$ \\ Gladir da Silva Cabral ${ }^{2}$
}

\begin{abstract}
In the Republican History of Brazil, the obsessive desire for modernization has been manifested in the political and economic culture of groups that assume the leadership of the State, either under the condition of elected governments or imposed by coups d'état. This article contextualizes the issue of environmental crisis by establishing a relationship with the "banality of environmental evil" contained in some of the major developmental projects designed during the Republican period (1889-1985). Finally, the paper examines the developmental trajectory through the telescope of Environmental History, armed with theoretical tools offered by some authors, including Hannah Arendt, Adorno, Edgar Morin, Enrique Dussel, and Paulo Freire.
\end{abstract}

Keywords: Eurocentrism; Developmentalism; Banality of Environmental Evil.

\section{Resumo}

Na História do Brasil Republicano, o desejo obsessivo de modernização vem se manifestando na cultura política e econômica dos grupos que assumem a condução do Estado, na condição de governos eleitos ou impostos por articulações golpistas. Este artigo contextualiza a questão da crise ambiental, estabelecendo uma relação com a "banalidade do mal" ambiental contida em alguns dos grandes empreendimentos desenvolvimentistas construídos ao longo do período republicano (1889-1985). Examina-se a trajetória desenvolvimentista por meio do telescópio da História Ambiental, munido com ferramentas teóricas oferecidas por alguns autores, entre os quais Hannah Arendt, Theodor Adorno, Edgar Morin, Enrique Dussel e Paulo Freire.

Palavras-chaves: Eurocentrismo; Desenvolvimentismo; Banalidade do Mal Ambiental.

\section{Introduction}

In order to understand the developmental praxis of environmental "banality of evil", it is advisable to discuss rationalities established with the modernity discourse. In this sense, contributions by the Frankfurt School and Hannah Arendt provide enlightenment. For Adorno and Horkheimer, in the transition from myth to enlightenment during Western modernity, a process of mastery of nature and formation of subjectivity, there is a regression to a new mythological phase whose results are still domination and violence. In the dialectic of Enlightenment "control and manipulation of nature, conditions necessary to civilization, exceed domination of man by man and of each individual over himself" (BASSANI; VAZ, 2011, p. 11).

\footnotetext{
${ }^{1}$ Professor do Programa de Pós-Graduação em Educação da Universidade do Extremo Sul Catarinense (UNESC), da Unidade Acadêmica de Humanidades, Ciências e Educação. E-mail: crc@ unesc.net.

${ }^{2}$ Professor da Universidade do Extremo Sul Catarinense, no curso de Letras e no Programa de Pós-Graduação em Educação. E-mail: gla@unesc.net
} 
For the Frankfurt School, "the impulse to dominate is born from fear of losing the own Self, a fear that reveals itself in each and every situation of threat to the subject in face of the unknown". For this reason, "myth and science have a common origin: to control unknown forces of nature, the uncontrolled multiplicity of the sensitive" (MATOS, 1993, p. 40-41).

This developmental action is a shift in relation between culture and nature. In traditional societies, this relation is also conflictual, but the correlation of forces is more balanced. With science and technology, modern society modified the correlation of this movement. While in mythic culture, the priest or the sorcerer mimics rituals in order to appease or to communicate with nature, using resources of modern science, man "turned nature into a huge analytical judgment of number, mathematizing it, formalizing it". That is, "if Enlightenment intended to demystify nature, unbewitch it, disenchant it, drawing on the explaining and dominant reason of natural phenomena, the result was, according to Adorno and Horkheimer, a triumphant misfortune" (MATOS, 1993, p. 46).

In the praxis of developmental enterprise, this triumphant misfortune contains an environmental "radicalism of evil". The concept of "banality of evil", used by Hannah Arendt (2013) in the case of the Eichmann Trial, can be applied to the rationalization of violence practiced in expansionist projects. As in the case of the violence practiced by the Nazi, "crimes" perpetrated against nature, indigenous peoples and non-human living beings are not acts of criminals and thieves, but works of ordinary people, public servants and employees of private sector, governmental authorities, scientists, engineers, etc., individuals deprived of capacity for reflection. This kind of institutionalized violence has the same logic of the Nazi Holocaust violence. The "Final Solution" for undesired human groups and non-human species is conceived and planned by a select group of authorities who determine the execution of the service for employees of the lower hierarchies. The problem with Eichmann, Arendt highlights (2013, p. 299), "was precisely that so many [other Nazis] were like him, and that the many were neither perverted nor sadistic, that they were and still are, terribly and terrifyingly normal". Therefore, "one must come to know the mechanisms that render people capable of such deeds [reference to Auschwitz], must reveal these mechanisms to them, and strive, by awakening a general awareness of those mechanisms, to prevent people from becoming so again", Adorno points out (2000, p. 121). ${ }^{3}$

The issue of modern violence is much more complex than the one that is broadcast daily in the news. The most frightening aspect of the tragic experience of Auschwitz is that "it is not the victims who are guilty, not even in the sophistic and caricatured sense in which still today many like to construe it"; the guilty ones were "those who unreflectingly vented their hate and aggression upon them". Thus, "[o]ne must labor against this lack of reflection, must dissuade people from striking outward without reflecting upon themselves" (ADORNO, 2000, p. 121).

Paulo Freire also offers us conceptual resources to face the developmental rationality of the environmental banality of evil. Freire (2013) believes that in the context of history, human groups are subject to humanization and dehumanization, and that the ontological condition of man is humanization but in the bosom of an oppressive society that affirms itself through injustice, exploitation, violence and domination, this condition is denied. Hence the need to develop a Pedagogy of the Oppressed, enabling "the recovery of his stolen humanity" (2013, p. 24). For the liberating role of the Pedagogy of the Oppressed to be understood, Paulo Freire (2013, p. 25-27) points out two key-aspects: the violence of the oppressors also makes them

\footnotetext{
${ }^{3}$ Based on Hannah Arendt (2013), we employ the concept of "environmental banality of evil" to characterize anthropocentric thoughts and practices of people considered as "normal" (ordinary people, governmental authorities, business authorities, technicians, engineers, managers, scientists, etc.), who practice trivial violence against natural environments (forests, woods, rivers, oceans, ecosystems in general) and non-human animals, without expressing any moral restriction or discomfort related to the violence practiced.
} 
dehumanized; therefore, "the great humanistic and historical task of the oppressed is to free themselves and their oppressors". To play this liberating role, the oppressed need to become aware of the fact that they "entertain the oppressor himself", for "only as they discover themselves to be 'hosts' of the oppressor can they contribute to the midwifery of their liberating pedagogy". As for non-human living beings, however, it is necessary to develop a consciousness that all of us - "humans" - are the oppressors, in one way or another.

These are theoretical resources we use to examine the developmental path in the History of Republican Brazil. In the text that follows, the reader will be able to better understand the sense of the "environmental banality of evil", used to illuminate the dark face of developmental modernity. In the first topic, we will show some perceptions about the environmental crisis. After that, we will analyze and question theoretical trends of developmentalism in Brazil; and, in conclusion, we will characterize the nature of environmental violence in some developmental enterprises occurring during republican governments, both under democratic and authoritarian regimes.

\section{Views of the environmental crisis}

During the decade of 1970, Arnold Toynbee (1976/1982) formulated the following question: will mankind kill Mother-Earth? More recently, the American geographer Jared Diamond (2005) and the British historian Ronald Wright (2006) addressed past socialenvironmental reasons for the collapse of great civilizations. Notwithstanding different perspectives and approaches, there is at least one convergent aspect in the way one sees and interprets mankind's path: civilizing and technological development is accompanied by a destructive and self-destructive violence.

Many other scholars of mankind's history also have addressed the causes of great civilization decadence and disappearing in the past. What makes us perplexed is that the signs of the crisis, which point to the eminence of a social collapse, have been explicated by more sensitive sectors of contemporary population of each and every society, as in the case of Greece and Rome, for instance. Now we are facing an environmental crisis in a globalized reality. In the field of science and philosophy, several researchers have been asking questions in order to better understand the nature of mankind. Alessandra Ninis and Marcos Bilibio (2012), for instance, propose reflection from an interdisciplinary dialogue between psychoanalysis, philosophy and social sciences; and the questions that encourage this dialogue bring us back to the same horizon envisaged by Toynbee, philosophers and other social scientists, illustrated by these questions: "Why do we kill ourselves and destroy our habitat? Why do we become slaves of consumption? Why can't we react effectively to the risk of our own death as species?"

The objective of Ninis and Bilibio (2012) is not the search for an answer to each question, but a reflexive provocation in a contemporary context of social alienation. Following the Frankfurt School, the authors question the dialectic of enlightenment, once one has forged a notion of progress with "the objective of freeing men from fear and make them masters" of nature. Enlightenment "arose to dissolve myths and nullify imagination, against which centuries of dogmatic domination had already resulted in huge impoverishment". Thus, "enlightenment relates itself with nature to manipulate it and dominate it, with the ultimate goal of production" (ADORNO, 2000 apud NINIS; BILIBIO, 2012, p. 48).

Ninis and Bilibio (2012, p. 53) problematize the conservative trend of modern society as a strong obstacle to face the environmental crisis. We are traditionally inclined to demand change of attitude from "the other", while the current crisis requires radical change not only in the economic system that dominates the planet, but especially in our consumerist and ecologically 
unsustainable lifestyle. In dialogue with Jung, the authors argue that in modern society the desire of dominating nature characterizes an environmental sociopathy fed by anthropocentric arrogance and the discourse of economic growth.

Henrique Leff (2006, p. 347) characterizes "environmental crisis" as a symptom of the globalized economic rationality: "Environmental crisis is a symptom - the mark on the being, on knowledge, on earth - of rationality based on an unbearable belief: of understanding and construction of the world conducted by the idea of totality, universality and objectivity of knowledge that led to the objectification and economization of the world" (LEFF, 2006, p. 347). The root of the environmental crisis, which is related to the "symbolic nature of human being" can be identified in the modern positivistic project that tried to establish a direct relation between "the concept and the real". Thus, "environmental crisis is not only a lack of significance of words, loss of references and dissolution of senses that post-modernity thought denounces: it is the crisis of the effect of knowledge on the world". Therefore, it is not a mere epistemological discussion centered on the idea of truth and objectivity of knowledge or of representation of the real, but of a knowledge that "turned itself against the world, intervened in it and displaced it". In concrete terms, "knowledge has de-structured ecosystems, degraded the environment, denaturalizing nature". For Leff (2006, p. 15-17), modern society has sunk itself into a self-destructive economic and scientific rationality.

\section{Historiography of developmental theories}

What is developmentalism? For Centro Internacional Celso Furtado de Políticas para o Desenvolvimento (Celso Furtado International Center for Development), a center that was created "with the purpose of honoring the path of the master", "developmentalism was a response to the challenges and opportunities created by the Great Depression of the 1930s"; and "national projects of development and industrialization in the outskirts were born in the same cradle that produced Keynesianism in central countries" (CENTRO CELSO FURTADO, 2015).

Pedro C. D. Fonseca (2004) searched for the "roots" of developmentalism in Brazil, characterizing his route in four currents: the nationalists, the defenders of industry, the Papelists and the positivists. Fonseca argues that nationalism, an ideology that emerges in the context of the crisis of the Portuguese colonial system and spreads in the course of the nineteenth century, was one of the central elements in the developmental ideal construction process. In the context of the First Republic, the industrialist project is born, culminating with controversies between groups that defended national development from agricultural economy and those who thought of development from the industrial economy perspective. The Papelists, in turn, "play an important historical role of bringing to the agenda an item that in the twentieth century would be significant to developmentalism: to admit credit, public deficit and loans as essential to leverage economy" (FONSECA, 2004, p. 238). In this path of thought formation, the role of positivists should be stressed, as they formulated ideas and actions to lead Brazil in the socalled natural way of civilization's evolution and modernizing progress. Positivists advocated an illuminative role to governmental actions, one they understood "to be duty of the State helping society to move towards progress" (FONSECA, 2004, p. 245).

On the path of developmentalism in the period from 1950 to 1970, Luiz Fernando Valente (2009) identifies three schools of thought: developmental conceptions formulated by 
Instituto Superior de Estudos Brasileiros [Higher Institute of Brazilian Studies] (ISEB, 1955) the concept of development conceived by the Escola Superior de Guerra [Higher School of War] (ESG, 1949) and theories disseminated by Escola Paulista de Sociologia [São Paulo School of Sociology] linked to USP (University of São Paulo). A nationalist, historicist and anti-imperialist group constituted ISEB; they advocated an industrial development through and alliance between the working class and the nationalist business class. Despite theoretical and ideological differences, many ideas adopted by ESG were connected to ISEB. The substantial difference was focused mainly on the "best" model of government that could conduct Brazil towards the developmental route. In this respect, ESG's basic doctrine supported a direct control of the political and social environment, for one would conceive that only the elites would be able to understand and implement the so-called "permanent national objectives" (VALENTE, 2009). USP School of Sociology, in turn, whose intellectual leadership included Florestan Fernandes and Fernando Henrique Cardoso, questioned theories formulated by ISEB and ESG members and even the "old left", led by the Communist Party. Unlike Rio de Janeiro schools, "São Paulo's adopted a cosmopolitan and structuralist, anti-dualistic perspective, emphasizing conflict of classes - that is, the dichotomy left-right - and rejecting the possibility of alliance between classes, instead of criticizing existing imperial relations between developed and non-developed countries" (PEREIRA, 2004, p. 8).

The singular aspect in the approach of Luiz Fernando Valente (2009) is the idea of thinking "development as practice of freedom". Valente dialogues with the thought of Paulo Freire aiming at pointing to another horizon as far as the meaning of development is concerned. Unlike conservative views that reduce development to economic growth and of the "old left" that advocates a tactic alliance to enable an "economic revolution", Paulo Freire advocates a notion of development coming out from ethical principles, social justice and human rights; he argues that one must not confuse development with modernization, for this primarily meets interests of imperialist major cities. In short, Paulo Freire thinks development beyond market economy, beyond a society that wants to format individuals as mere economic agents. Freire projects an idea of formation and development of "citizens aware of their status in the world and jointly integrated in the national community" (VALENTE, 2009, p. 190).

Poder, redes e ideologia no campo do desenvolvimento (Power, networks and ideology in the field of development) is the approach outlined by Gustavo Lins Ribeiro (2008). Ribeiro (2008, p. 110) characterizes and contextualizes the concept of "development" as a field of power that rises and expands itself along with modern capitalism; a field of power that has been formatting itself in institutional networks and social actors through "several segments of local populations" (for example, local elites and leaders of social movements); private businessmen, employees and politicians in all levels of government; staff of national, international and transnational corporations (for example, different types of contractors and consultants); and staff of international organizations of development (for example, employees of multilateral agencies and regional banks)". Since the Industrial Revolution, the idea of "development" has been configuring itself as an ideology and utopia of Western modernity, stimulating and justifying the "construction of large scale infrastructure projects (PGEs) such as channels, railways, dam and other great works that form the quintessence of the so-called development projects"; and these mega-projects "have been supported by powerful institutions - such as

\footnotetext{
${ }^{4}$ Among the main ISEB intellectuals, these one stand out: the philosophers Álvaro Vieira Pinto, Roland Corbisier and Michel Debrun; the sociolgist Alberto Guerreiro Ramos; the economists Ignácio Rangel, Rômulo de Almeida and Ewaldo Correia Lima; the historian Nelson Werneck Sodré and the political scientists Hélio Jaguaribe and Cândido Mendes de Almeida (PEREIRA, 2004).
} 
governmental and multilateral organizations, engineering schools, banks and industrial corporations - , that have played important roles in political economy over the last two centuries" (RIBEIRO, 2008, p. 11-112).

What are the sources of the developmental thought? Fernando Nogueira da Costa (2012) points out the influence of German economist Georg Friedrich List (1789-1846) and of the British economist John Maynard Keynes (1883-1946); of intellectuals linked to CEPAL Comissão Econômica para a América Latina e o Caribe (Economic Commission for Latin America and the Caribbean), an organ created by the UN in 1948; the contribution of the "utopic socialists", influence, usually ignored by historiography of developmentalism (Cf. COSTA, 2012); the influence of positivists; the contribution of the first and the second generation of Escola de Campinas and the new developmentalism is perceived from the beginning of the twentieth century, with emphasis on "leftist developmentalism", represented by Unicamp's second generation.

In the field of economic thought, no other Brazilian intellectual achieved as much international recognition and influence as Celso Furtado. He was one of the first Latin American intellectuals to propose a theory of development for Latin America beyond classical approaches of Europe and North-America intelligence. His experience at CEPAL during the 50s, along with other Cepaline intellectuals, incited him to develop a structural-historical method to understand the socio-economic dynamic of Latin American and "underdeveloped" countries' reality. Celso Furtado rejects the market perspective of neoclassicism, refuses the ideological perspective of Marxist economists, and makes a selective appropriation of the Keynesian experience for Latin America's reality. The Cepalin-Furtadian theory proposes theorization beyond colonial domination. Furtado refuses the traditional neoclassic interpretation of "comparative advantages"; demystifies the traditional positivist view that considers "underdevelopment" as a lower stage of the evolutionary process that leads to development; and consequently develops the theory of underdevelopment, in which he explains the structural and dependent logic between "developed" and "underdeveloped" countries, that is, the latter fulfilling a peripheral and subordinated function, although necessary, in the international capitalist system. Thus, the path to Latin America's "development", pointed out by the Cepalin school, has one single direction: to invest in national economy industrialization, attributing a Keynesian role to the State (FURTADO, 1983; 2000; 2009).

Chilean historian Fernando Mires (2012) defines Latin America developmentalist thought as a result of internal colonialism or "endocolonialism". By endocolonialism "one wants to designate a generalized behavior of a country's population, oriented to economic booty, turning nature and those who live from it to exploitable and manipulable" (MIRES, 2012, p. 88). For Mires, the theory of economic dependence is not only a harmful ideology, but also an internalized cultural heritage assimilated by Latin-American population. In Latin America, the discourse of dependence was and has still been used by dictators of the capitalist field and politicians identified with socialist ideals. Today, this author highlights $(2012$, p. 86), "the argument of dependence is also used to hide national and local responsibilities for damages against nature and, therefore, to the respective countries' population".

During the first two decades of the twentieth century, what is most striking in developmentalist historiography is the lack of an environmental critique with regard to socialenvironmental impacts caused by developmentalist policy. Even in the face of historical and contemporary evidences of environmental devastation and the current ecological situation of the Planet, according to reports made available by Painel Intergovernamental sobre as Mudanças Climáticas (Intergovernmental Panel on Climate Changes - IPCC), one can see, in different theoretical fields of developmentalism, an instrumental use of nature. Practically every 
theoretical field ignores the predatory, anthropocentric and the Eurocentric logic of the concept of development. They ignore the social-environmental "banality of evil" and do not recognize the existence of a tradition of environmental critique in the history of Brazilian social thought (PÁDUA, 2004; FRANCO; DRUMMOND, 2009).

\section{The developmentalist ideology in school environment}

I was a substitute professor of Natural History at Colégio Pedro II when I planned a book which dealt with animals, vegetables and minerals under the point of view of their importance to national economy, and pointed out to Brazilians the huge natural resources whose exploration would give us prominent place among the world's large powers. I didn't know any work in the genre, but proceeded to a thorough inquiry at bookstores and libraries to see if there was anything similar to what I imagined. I convinced myself that "my book" would fill in a "gap" and started to think of gathering the material I needed in order to elaborate "O Brasil e Suas Riquezas" (Brazil and Its Wealth). (Waldemiro Potsch, 1956).

Since the process of independence (1822) and specially from the First Republic on (1989), Brazilian governments have been perpetuating a "Final Solution" for indigenous peoples, forest ecosystems and non-human living beings; and this form of "banality of evil" has been still employed over these two first decades of the twenty-first century, as reports of researchers and non-governmental entities such as Conselho Indigenista Missionário (CIMI), SOS Mata Atlântica, Instituto Nina Rodrigues and hundreds of other institutions have shown. Certainly, the expression "final solution" can be applied to the Brazilian case only in a very limited way. In the case of the Nazi, their attempt was to eliminate the Jewish people through mass murder. In spite of the dreadful way in which the Brazilian authorities have driven their mega projects, death and despoliation was a by-product than an intention. So, while it is possible to think the banality of evil is appropriate in that people see themselves carrying out a function from higher authority, what was done is not comparable with a Nazi Final Solution.

Yes, developmental modern rationality contains a form of environmental banality of evil that stimulates and naturalizes practices of "final solution" against natural ecosystems and non-human animals, both on the daily life of ordinary people and in the framework of institutions in general: companies (national and foreign), schools, governmental organs, bank institutions, international organizations, etc. Throughout the twentieth century, developmental thought has been consolidated as a field of power, and the ideology of progress was one its most powerful dogmas.

In the field of education, developmental thought invaded the classroom through school subjects, textbooks and several other pedagogic resources. Among the thousands of textbooks that have circulated through educational spaces, one of the most representative works of developmental thought is $O$ Brasil e suas riquezas (Brazil and its Wealth), by the physician and professor of Natural History Waldemiro Potsch, a book published and reedited dozens of times since 1921 until the decade of 1980. At every issue, Potsch exalted the editorial success, as in the $32^{\text {nd }}$ edition (1965), where he highlights the circulation of 440000 copies and the publication in Italian and English. As an exponent sample of the conservative liberal thought, Potsch foresaw a glorious future for Brazil, taking into account the exploration possibilities of many of "our" natural wealth. Brasil e Suas Riquezas is a developmental apology that conceives Brazilian continental nature as a huge amount of resources to be explored. Waldemiro Potsch expresses his patriotic view in the future of Brazil, exalting statistics that emphasize the 
characteristics of a developmental model of both Eurocentric and Anthropocentric nature. In his most known work, he lists industries and Brazilian industrial progress; economic exploitation of non-human animals (cattle, buffalos, pigs, horses, donkeys, asses, sheep, goats, birds, poultry, the export of alligator skin, the export of lizard skin, the export of fish, etc.); the situation of Brazilian flora (Amazon), the situation of farming exploitation (coffee, rice, corn, sugar cane, cotton, bean, cassava, wheat, banana, Irish potato, oranges, etc.); the situation of the mineral wealth (iron, manganese, gold, diamond, mica, quartz, nickel, silver, zinc, etc.); the situation of the national industry, of communications and transportation. (POTSCH, 1956; 1965). The developmental conception of Potsch is situated in the scope of the thought that conceives nature as a resource, a Eurocentric and anthropocentric view that naturalizes the environmental banality of evil. In the 1965 edition, Potsch optimistically greeted "the March $31^{\text {st }} 1964$ revolutionary movement of the Armed Forces" and expressed his approval on NorthAmerican politics of the "Alliance for the Progress".

Until the decade of 1980, textbooks of History and Geography were also strategic vehicles for spreading developmental thought. During the period of the 1964 military regime, school space was oriented in curricular terms to teach "patriotic order" and "industrial progress"; and textbooks of Moral and Civic Education, History and Geography, mainly, were publicity instruments of large military governments developmental enterprises (Cf. POCHMANN; CAROLA, 2016). In the backstory of each large developmental project, however, there were traces of a war whose victims were killed, silenced and buried. If we were to do an investigative archaeology of each large work built by all governments, such as investigations carried out recently by Comissão Nacional da Verdade [National Commission for the Truth] (Brasil, CNV, 2012-2014), we would find traces of corruption, corpses and several forms of social and environmental violence. Let's look at the environmental banality of evil, in the examples of some developmental mega-projects carried out by Brazilian governments.

\section{Developmental mega-projects and the hidden reality of the environmental banality of evil}

Before we approach some of developmental mega-projects of Brazilian republican history, we find it important to make a brief reflection on the epistemological cradle of developmental thought: the discourse of Western modernity. During the modern period, imperialist countries of Western Europe disseminated a Universalist and Dualistic discourse (center and periphery, civilized and wild, old and modern, etc.); emphasized positive aspects in cultural, social and civilization terms. In addition, "Europeans imagined also being not only exclusive bearers of such modernity, but equally their exclusive creators and protagonists." (DUSSEL, p. 111); and imposed a modernization paradigm built with the resources of violence, domination, exploitation, robberies and raids in Americas and other peripheral countries of the Western order.

The imperialist face of Western modernity can be visualized in Goethe's Faust. In his last personification - the fomenter - Faust "connects his personal paths with economic, political and social forces that run the world", stage of life in which "he learns to destroy and to build" (BERMAN, 1986, p. 60-61), the ideal of society's modernization turned into a developmental tragedy. In the work of Goethe, Faust dedicates himself to the mission of modernizing the world; he "envisions, and fights to create a world where personal growth and social progress may be reached with a minimum of human sacrifices". Faust, Berman says (1986, p. 66), "pretending not only to others but to himself that he could create a new world with clean hands; he is still not ready to accept responsibility for the human suffering and death" 
caused by his modernization project of the world. Firstly, "he contracted out all the dirty work of development"; afterward, "he washes his hands of the job, and disavows the jobber once the work is done". 5

In the case of Brazil, cultural types that historically have been run over by the progress of developmental modernization are the indigenous people and several communities who live a subsistence way of life (quilombolas [ $19^{\text {th }}$ century African-Brazilian fugitive slaves], coastal communities, rubber tappers, artisanal fishermen, traditional agricultural communities, etc.). Additionally, we cannot stop considering that the rationality of the "final solution" also reaches non-human animals and thousands of other living beings not considered by homo sapiens antropocentricus or by homo sapiens demens, to use Edgar Morin's expression, when he problematizes the frontier between the rational and the irrational.

In the history of independent and republican Brazil, the fate of developmental modernization has a very significant place of symbolic birth: the construction of the MadeiraMamoré railway, known as Ferrovia do Diabo (FERREIRA, 1960/1982), and Trem Fantasma (HARDMAN, 2004/2005). In a metaphorical sense, the history of the Madeira-Mamoré railway construction in the Amazon symbolizes Goethe's Faust in Brazil, that is, it represents the covenant of Brazilian elites with the "devil", motivated by the obsessive desire for modernization with the destruction and taming of wild nature. It is the first great developmental tragedy promoted by the Brazilian government, in partnership with international capitalism, the Brazil Railway Company, of North-American entrepreneur Percival Farquhar. The railway was built in the period from 1907 to 1912, connecting Porto Velho to Guajará-Mirim (State of Rondônia), covering approximately $360 \mathrm{~km}$ through the Amazon forest.

During the construction of the work (1907 to 1912), the Madeira-Mamoré Railway Company hired 21,817 workers, and official records released by the company and registered at hospital de Candelária inform a total of 1,552 casualties (FERREIRA, 1982, p. 301). But the official numbers do not reveal the whole truth of this developmental tragedy. Taking into consideration freelance jobs and non-registered workers, Ferreira estimates in approximately 30000 the total number of workers and over 6,200 casualties (FERREIRA, 1982, p. 301-302). ${ }^{6}$

The war triggered by the developmental project in the Amazon jungle has some similarities with Guerra do Contestado, in Santa Catarina. The conflict occurred in the region of Santa Catarina's plateau from 1912 (year of the Madeira-Mamoré railway inauguration) to 1916. During that time, there were "erva mate" cultivation and forest resources of great interest for logging companies. Who were the protagonists of the war? On the developmental side there was the federal government, the national army and the state governments of Santa Catarina and Paraná, in partnership with Southern Brazil Lumber \& Colonization Company, of Brazil Railway Company,

\footnotetext{
${ }^{5}$ This scene resembles the servile and bureaucratic behavior of Eichmann in Jerusalem, the theatrical landscape of the Nazi's trial, organized by the State of Israel. Contrary to what was disseminated in the media spectacle of the trial, the Nazis were not individuals naturally perverted, cruel or monstrous. In the specific case of Eichmann, Hannah Arendt (2013) described him as an ordinary guy, a role model employee in compliance with law and order, a citizen who supported and contributed to the building project of a "new world". Eichmann, however, was a man deprived of the ability to reflect and indifferent to the sacrifice of some, because he was committed to a higher cause, with the irrational racist project of an Aryan society; he was (or is) a social type characteristic of massed and militarized societies, which leads us to conclude that, a tragic violence such as the one of the Holocaust, can be committed by normal guys.

${ }^{6}$ Another aspect that draws attention in the construction of the Madeira-Mamore railway, is the ethnic diversity of the workers, with approximately 50 distinct nationalities: Brazilian, Spanish, West Indies, Portuguese, German, Italian, Colombian, American, Bolivian, French, Venezuelan, Russian, Cuban, Greek, English, Chinese, Puerto Rican, Austrian, Mexican, Turkish, Arabic, Peruvian, Swedish, Belgian, Canadian, Chilean, Japanese, Danish, Scotish, Hungarian, American Indians, Norwegian, Panamanian, Argentinian, Ecuadorian, Hindus and many other unknown (HARDMAN, 2005, p. 166).
} 
also of Percival Farquhar. On the other side, Caboclos of Contestado, a population who lived in the region and made their living through a subsistence economy, and farmers who felt threatened in losing their properties.

As in the case of Ferrovia do Diabo, in Contestado War, there is a history of conflicts and political disputes for the control of the land before and after the main confrontation. In addition, one of the main characters of the conflict was also the North-American entrepreneur Percival Farquhar, who acquired the control of Companhia de Estrada de Ferro São Paulo-Rio Grande in 1908 and was generously bestowed by the first Brazilian republican government with a concession of $15 \mathrm{~km}$ land exploration on both sides of the railway, which culminated with expropriation of over 6 thousand $\mathrm{km}^{2}$ of land where the cabocla population lived. The government facilitated the Lumber (subsidiary of Brazil Railway Company) enterprise, decreeing the region where "caboclos" communities lived as vacant ground and granting contractual advantages to the subsidiary. In the field of construction work, Farquhar hired around 8000 workers. In the field of Constestado War, the Brazilian government mobilized around 6000 soldiers from the army (practically half of the troops at the time) against 8000 caboclos armed with old shotguns, large knives and agricultural tools. The historiography estimates a slaughter of over 10000 people, a brutal violence of the Brazilian army, very similar to the one employed in the Canudos War (HARDMAN, 2005; CPDOC, 2012; MACHADO, 2011). ${ }^{7}$

Political instability and repeated failures of developmental enterprises reinforced the need of putting an end to the First Republic regime. In the decade of 1930, new Brazilian elites who took hegemonic control of the State under the leadership of Getúlio Vargas, created the basic conditions for the "developmental era". With Vargas in control of the executive, the State is equipped to provide the necessary infrastructure to build national industry and optimize the economy in the international scenario. With the "Estado Novo" project, Getúlio Vargas redefined the role of the State and implemented industrialist rationality; used administrative structure to develop a national economy based on a more efficient exploration planning of the huge "giant Brazil" natural resources, which was deemed as still asleep. In this context, Brazil and the Brazilians got to know the first historical version of Plano de Aceleração do Crescimento Econômico [Economic Growth Acceleration Plan] (PAC-Vargas).

During Getúlio Vargas' administration (1930-1945; 1951-1954), environmental violence was also present in several developmental projects, among which the deployment of Companhia Siderúrgica Nacional (CSN), founded in 1941 and installed in 1946, a vital enterprise for the consolidation of national industry basic structure and for the coal industry in the states of Santa Catarina ${ }^{8}$ and Rio Grande do Sul; the colonization policy of Estado Novo (1937-1945), also known as "Marcha para o Oeste" (March to the West), whose objective was the social and economic integration of the current states of Mato Grosso, Mato Grosso do Sul, Goiás, Tocantins and south of Pará (MARTINEZ, 2011); and the creation of Petrobrás (1953).

\footnotetext{
${ }^{7}$ The way journalists, chroniclers, military and first historians described and represented the Contestado's conflict is also revealing. The speeches of the time highlighted that the ideal of modernity and the developmental spirit already dominated the cultural environment of the main Brazilian cities in the early twentieth century. All in all, the conflict was interpreted as consequence of an "ignorant" and religiously fanatic population, opposed to Brazil's "order and progress", as one can see in denominations widespread to characterize the conflict: war of fanatics, war of gunmen, holy war, war of country people (CPDOC, 2012).

${ }^{8}$ In the south of Santa Catarina, economic progress promoted by the coal industry since the decade of 1930 resulted in one of the greatest social-environmental tragedies of History in Brazil. Besides the high number of casualties caused by work accidents and diseases caused by pollution, there was an environmental devastation of river basins, soil and air in tragic proportions.
} 
During the golden years, a young representative of civil society won presidential elections. Juscelino Kubitschek took office promising not only the continuity of the industrialization process and the economic development, but firmly affirming that Brazil would grow 50 years in only five. Now we are facing the version of PAC-JK. If we observe his Target Plan in a social-environmental perspective we can easily envision the conception of implicit nature in his ambitious project. The Plan was divided into five big sectors of investment: energy, transportation, food, basic industry, and education. As in previous and subsequent governmental plans, JK government didn't prioritize crucial problems of Brazilian reality such as income and land concentration, social inequality, let alone some effective measure of environmental protection as conservative environmentalists claimed. JK mobilized the State to leverage and accelerate economic growth believing that this growth by itself would solve the main social problems of Brazil. In his speeches to the congress, he would say that the Target Plan aimed at a "harmonic expansion" through "the use of dormant powerful energies" that were asleep in Brazilian territory; he would argue that with the implementation of "civilization in the farthest corners of the country" it would arise, "by God's will, a time of abundance and genuine fraternity that would, without distinction, allow all Brazilians the fruition of culture and progress" (BRASIL, 1960, p. XXIX). Despite the social and environmental tragedy, ignored and not reccounted, JK and his architects were also bestowed with a prominent place in the official memory of Brazil's History.

During the administration of João Goulart (Jango), Brazil experienced the possibility of carrying out Base Reforms that promised development with income distribution and social inclusion. However, the ultimate goal of Jango's government was also transforming Brazil into a modern nation. In his brief government, he tried to unify "all lucid and progressive Brazilians" to "accomplish the noble task of transforming an archaic society into a modern nation, truly democratic and free" (BRASIL, 1964, p. V-VI). Jango was not a Marxist, neither a communist nor a leftist politician, as the architects of 1964 Coup accused him of being; he was a gaucho farmer attuned with the labor policy and supporter of liberty and justice ideals advocated by modernity. The combination of the Cold War climax, the winds of 1959 Cuban Revolution and the increasing mobilization of social movements triggered by the fight for Base Reformations maximized fear and panic of the forces of the right, culminating with the Coupe D'état that was already underway since president Jânio Quadros' resignation.

During the years of dictatorship and torture, the civil-military government of 1964 established the dictatorship of capitalist "order and progress". In this period of ostracism, society was called on to assimilate the Brazilian economic "Miracle's" PAC. The military government wanted to show to great Western superpowers its ability to place the Brazilian State at the service of international capitalism. For this purpose, the government decided to exploit the contemporary world's largest rain forest. They created and authorized hundreds of natural resource exploration projects in the Amazon; they built a mega infrastructure of highways and hydroelectric plants; they formed financing, research and planning agencies and offered tax incentives to businessmen, avid for short-term enrichment. The mega enterprises had huge social-environmental impacts. The dimension of the insane and perverse developmental conception, that is, the tip of the iceberg can be seen in five mega projects: Projeto Jari, idealized and initiated in 1967 by the American billionaire Daniel Keith Ludwig in partnership with entrepreneur Joaquim Nunes Almeida; the construction of Transamazônica highway, inaugurated in 1972 by General Emílio Garrastazu Médici; Projeto Grande Carajás, a program of mineral exploration launched in 1980 under the leading of Companhia Vale do Rio Doce (CVRC), a state company privatized in 1998; the construction of Usina Hidrelétrica of Tucuruí, 
inaugurated by General João Batista Figueiredo in 1984 (PICOLI, 2006); and in the construction of Usina Binacional de Itaipu (Itaipu Binacional Hydroelectric Dam).

From 1970 on, the Brazilian government built many highways in the Amazon, among which Transamazônica, with over 5 thousand kilometers, linking the Northeast to the border of Peru; and Rodovia Santarém-Cuiabá (BR-165), linking North and South of Brazil and crossing the Center-West region. Each large enterprise had the participation of foreign companies and financial loans from Interamerican Development Bank and World Bank, which means that the environmental banality of evil promoted by developmental projects is also an enterprise of international capitalism. Besides unrecorded and ignored environmental damages, what kind of violence is seen in the construction of mega-projects? Who have been the main victims of progress in the Amazon jungle highways?

In general, indigenous peoples were the ones who suffered the most the impact of developmental modernity in the Amazon. With the construction of highways, indigenous groups such as the Parakanân, the Kréen-Akaróre, the Cintas-Largas, the Suruí, the WaimiríAtroarí, the Yanomami and others were forced to move to other territories or face the implacable reality of the modern world; and hundreds died from non-Indian diseases and from the corruption of traditions through contact with white men (DAVIS, 1978).

The violence against indigenous peoples during the 1964 military dictatorship is still much more radical than the one reported by Shelton Davis. The genocide of indigenous groups was witnessed and denounced by international entities, and the government of generals was pressed up to take some official measures. With the recent disclosure of the Figueiredo Report through Comissão Nacional da Verdade, Brazilian society gained the international news again because of the terrible slaughter against indigenous peoples during the military regime. The Report was organized by Jader Figueiredo, president of Comissão de Investigação [Commission of Investigation] (CI), created to investigate complaints of corruption and irregularities in Serviço de Proteção ao Índio [Service of Protection to the Indian] (SPI). The work was concluded in 1968, but only now has become public. The Report contains approximately seven thousand pages and in it one can find the record of several brutal forms of physical and symbolic violence, practices of genocide, tortures, compulsory labor, epidemics, sexual abuse and many other forms of evil. Besides a long list of SPI agents accused in the process, the reporter nominated a list of crimes, among which murder, prostitution, slave labor and dilapidation of indigenous heritage. ${ }^{9}$

In each large enterprise built in the Amazon by the government of the generals, there is a record of corruption and several forms of socio-environmental evil. Because of the regime of press censorship and repression to critical thinking, many of the critiques came from abroad. However, the praxis of environmental violence also counted on the complicity of a large part of Brazilian society. For the more conservative sectors of mainstream media, for the business class, politicians and even more intellectualized sectors of the academia, the removal or expulsion of indigenous peoples from their traditional lands was an inevitable necessity in order to enable Brazil's "economic progress". For many journalists and writers who manifested themselves through the media, "the destruction of aboriginal populations of the Amazon Basin

\footnotetext{
9 "1. Murder of Indians; prostitution of Indian women; Abuse; Slave labor; Usurpation of Indian labor; Appropriation and deviation of resources coming form indigenous heritage; Dilapidation of indigenous heritage: a) Cattle sale; b) Land lease; c) Wood sale; d) Exploration of minerals; e) Chestnut sale and other products of extractive activities; f) Handicraft products sale; g) Criminal donation of land; h) Vehicles sale. 2. Range of incalculable amounts; 3. Adulteration of official documents; 4. Fraud in process of accounts proof; 5. Deviation of budgetary funds; 6. Irregular application of public money; 7. Omissions; 8. Fraudulent Admissions of employees; 9. Administrative negligence" (BRASIL, 1968).
} 
was a sad consequence, although necessary" for a country that had chosen the route of industrial and technological development (DAVIS, 1978, p. 103).

Another developmental mega-project by the generals was the construction of Itaipu Hydroelectric Plant, located in the river basin of Paraná River, on the border between Brazil and Paraguay. The project was conceived, projected and executed by the bureaucratic engineering of the military governments of both countries, in the period between 1975 and 1982. As all the other large enterprises built by the 1964 military regime, Itaipu forms the mosaic of Mammoth works that intended to turn Brazil into a world power.

On the Brazilian side, Usina de Itaipu encompassed, by the time of its inauguration, approximately 110000 ha of area and eight cities of Paraná State far-west region. Around 40 000 inhabitants were affected by the project of the largest Hydroelectric Plant in the world, back then (GERMANI, 2003). Nowadays, the reservoir covers $1,350 \mathrm{~km}^{2}$ of inundated area and is "just" the seventh largest reservoir in Brazil (BRASIL/PARAGUAI, 2015). In an apologetic tone, Itaipu Binacional institutional website reveals the "grandiosity" of the enterprise: the volume of concrete used amounts to 210 Maracanã soccer stadiums; the quantity of iron and steel amounts to 380 Eiffel Towers; the volume of earth and rocks removed to build the work was 8.5 larger than the Eurotunnel that links France to England at the English Channel, and 15 times more concrete (BRASIL/PARAGUAI, 2015). ${ }^{10}$

But what was the socio-environmental cost of Itaipu? While the government exalted with patriotic pride the magnitude of the largest Hydroelectric Plant in the world, environmentalists and activists of Movimento Justiça e Terra [Movement Justice and Land] (MJT) denounced the consequences not taken into consideration by bureaucrats of both governments. Juvêncio Mazzarollo, one of the last political prisoners of the 1964 military regime, witnessed the expropriation of Guarani Indians and small farmers and revealed to the world the socio-environmental cost of Itaipu. Like the tourist who bows down in awe before the pyramids of Egypt or the great cathedrals and palaces that symbolize the grandeur of great civilizations of the past, the tourist who nowadays visits Usina de Itaipu and its outskirts does not perceive the socio-environmental holocaust buried under water and concrete.

The work started to be built in 1975 and the construction of the dam $-1,350 \mathrm{~km}^{2}$ - was concluded in 1982. At the height of construction, around 40000 workers were hired and approximately 10000 houses were built, along with social clubs, sports and recreation centers, hospitals, schools, and churches. On the Brazilian side, around 40000 people were displaced and on the Paraguayan, approximately 20000 . The work was initially budgeted at US\$2.5 billion and reached around US\$ 20 billion, including debt resources to be paid off until 2023 (MAZZAROLLO, 2003). In comparison with the capacity of investment and production of neighboring countries and the great works of rich countries, the socio-environmental cost of the Itaipu enterprise is frighteningly (although it had been seen with pride and admiration by many) immeasurable. While "the Siberian gas pipeline was considered by industrialized countries as 'the business of the century', here in the Republic of the generals "Brazil in fact was running several 'businesses of the century' simultaneously - Itaipu, Carajás, Programa Nuclear, Ferrovia do Aço, Tucurui and Tubarão plants, São Paulo and Rio de Janeiro subways and a huge list of etceteras." (VANESKI FILHO, 2012, p. 208).

In short, Itaipu Binacional enterprise is just another undisputed example of Goethe's Faust developmental spirit in Brazil. A titanic work that exceeds in material and human resources the Pyramids of Egypt; an economic cost way behind what was estimated and

\footnotetext{
${ }^{10}$ Besides the data above, the official website of binational offers to its visitors a series of other comparisons with other countries in terms of capacity of energy production; it also shows its current environmental policy and social responsibility.
} 
projected, with reports of overbilling and corruption that were not investigated; an immeasurable social cost, tempered through the organization of expropriated population and the support of civil entities (sectors of the Catholic Church, the Evangelical Church, OAB, among others); and an "ecological holocaust", which still today has not been precisely perceived in its dimension and consequences.

In the final context of the mammoth spirit of the Brazilian military regime, Dom Hélder Câmara expressed his conviction that, "the larger the project, the less it served the poor"; and now he can add: it does not serve the poor, the indigenous peoples, the traditional communities (small farmers, rubber tappers, artisanal fishermen, quilombolas, among others) and much less non-human animals.

\section{Final Considerations}

Critique of the developmental spirit explained in this article does not pretend to disregard the need for economic development policy deployment. Our purpose was to show the lack of environmental sensitivity in the framework of theoretical and political formulations that enabled large enterprises; to demonstrate that Brazilian economists, as well as researchers who dedicate themselves to the study of Economic History in Brazil, have not understood yet or don't acknowledge the seriousness of the environmental crisis and climate changes.

In a globalized world, dominated by the capitalist system it is necessary to analyze and encompass the totalitarian dimension of developmental dialectics. What one observes and notes in the history of great developmental enterprises is that, through the State, a "Final Solution" has been planned and executed for both human and non-human populations, for forests and natural ecosystems. In the specific case of Brazil, historiographical and documental sources reveal that indigenous peoples, traditional communities, forests and non-human animals have been suffering a kind of "holocaust" rationally planned, but hidden and legitimated by the developmental paradigm since Republican independence.

\section{References}

ADORNO, Theodor W. Educação e emancipação. 2. ed. Trad. de Wolfgang Leo Maar. São Paulo: Paz e Terra, 2000.

ARENDT, Hannah. Eichmann em Jerusalém: um relato sobre a banalidade do mal. Tradução de José Rubens Siqueira. 16 reimpressão. São Paulo: Companhia das Letras, 2013.

BASSANI, Jaison José; VAZ, Alexandre Fernandez. Sobre o domínio da natureza na filosofia da história de Theodor W. Adorno: uma questão para a educação. Rev. Bras. Educ., v. 16, n. 46, Rio de Janeiro, p. 9-32, Jan./Apr. 2011.

BERMAN, Marshall. Tudo que é sólido desmancha no ar: a aventura da modernidade. São Paulo: Cia das Letras, 1986.

BRASIL. Comissão Nacional da Verdade. In: http://www.cnv.gov.br/institucional-acessoinformacao/a-cnv.html. Access on 30/01/2017.

BRASIL. Mensagem ao Congresso Nacional remetida pelo Presidente da República na abertura da sessão legislativa de 1960. Rio de Janeiro: Imprensa Nacional, 1960.

BRASIL. Mensagem ao Congresso Nacional remetida pelo Presidente da República na abertura da sessão legislativa de 1964. Rio de Janeiro: Imprensa Nacional, 1964.

BRASIL. Os Presidentes da República Velha. Brasília: Câmara dos Deputados, Câmara Notícias, 28/12/2006. Available at: <http://www2.camara.leg.br/camaranoticias/noticias/97123.html>. Acesso em: 29 Sep. 2015.

BRASIL. Relatório Figueiredo. Brasília: Ministério do Interior, 1968. Disponível em: <http://pt.scribd.com/doc/142787746/Relatorio-Figueiredo>. Access on 30 Sep. 2015. 
BRASIL/PARAGUAI. Itaipu Binacional. Available at: <https://www.itaipu.gov.br>. Acesso em: 8 Sep. 2015.

BUARQUE, Cristovam. A desordem do progresso: o fim da era dos economistas e a construção do futuro. 3. ed. Rio de Janeiro: Paz e Terra, 1991.

COSTA, Fernando Nogueira da. Desenvolvimento do desenvolvimentismo: do socialismo utópico ao social-desenvolvimentismo. Texto para discussão. IE/UNICAMP, Campinas, SP, n. 205, May 2012. Available at: <www.eco.unicamp.br/docprod/downarq.php?id=3185\&tp=a>. Access on 8 May 2015. CPDOC. Dossiê Guerra do Contestado. Rio de Janeiro: FGV, 2012. Disponível em:

<https://cpdoc.fgv.br/contestado>. Access on 29 Sep. 2015.

DAVIS, S. H. Vítimas do Milagre: o desenvolvimento e os índios no Brasil. Tradução de Jorge Alexandre Faure Pontual. Rio de Janeiro: Zahar, 1978.

DUSSEL, Henrique. Europa, modernidade e eurocentrismo. In: LANDER, Edgardo (Org.). A colonialidade do saber: eurocentrismo e ciências sociais: perspectivas latino-americanas.

ColeccionSurSur, CLACSO, Ciudad Autónoma de Buenos Aires, Argentina, set. 2005. Available at <http://bibliotecavirtual.clacso.org.ar/clacso/sur-sur/20100624093038/5_Dussel.pdf>. Access on 10 Apr.2015.

DUSSEL, Henrique. Europa, modernidade e eurocentrismo. México: Universidad Autónoma Metropolitana Iztapalapa (UAM-I). Available at: 〈http://enriquedussel.com/txt/1993-236a.pdf>. Access on 10 Apr. 2015.

FERREIRA, Manoel Rodrigues. A ferrovia do diabo: história de uma estrada de ferro na Amazônia. 3. ed. São Paulo: Melhoramentos, 1982.

FONSECA, Pedro C. D. Gênese e precursores do Desenvolvimentismo no Brasil. Pesquisa \& Debate 15, n.2, v. 26, p. 225-56, 2004.

FRANCO, José Luiz de Andrade; DRUMMOND, José Augusto. Proteção à natureza e identidade nacional no Brasil, nos anos 1920-1940. Rio de Janeiro: Fiocruz, 2009.

FREIRE, Paulo. Pedagogia do oprimido (O manuscrito). São Paulo: Instituto Paulo Freire;

Universidade Nove de Julho (UNINOVE); Ministério da Educação (MEC), 2013.

FURTADO, Celso. Desenvolvimento e subdesenvolvimento. 5. ed. Rio de Janeiro: Contraponto/Centro Internacional Celso Furtado, 2009.

FURTADO, Celso. O mito do desenvolvimento econômico. Rio de Janeiro: Paz e Terra, 1974.

FURTADO, Celso. Teoria e política do desenvolvimento econômico. 10. ed. São Paulo: Paz e Terra, 2000.

GERMANI, Giomar Inez. Expropriados, Terra e água: o conflito de Itaipu. 2. ed. Salvador: EDUFBA/ULBRA, 2003.

HARDMAN, Francisco Foot. Ter-fantasma: a ferrovia Madeira-Mamoré e a modernidade na selva. 2. ed. São Paulo: Companhia das Letras, 2005.

LEFF, Henrique. Racionalidade ambiental: a reapropriação social da natureza. Tradução de Luis Carlos Cabral. Rio de Janeiro: Civilização Brasileira, 2006.

MACHADO, Paulo Pinheiro. Guerra, cerco, fome e epidemias: memórias e experiências dos sertanejos do Contestado. Topoi, v. 12, n. 22, 2011, p. 178-186. Available at <http://www.revistatopoi.org/numero_atual/topoi22/topoi\%2022\%20\%20artigo\%2010.pdf>. Access on 29 Sep. 2015.

MATOS, Olgária C. F. A escola de Frankfurt: luzes e sombras do iluminismo. São Paulo: Moderna, 1993. $127 \mathrm{p}$.

MAZZAROLLO, Juvêncio. A taipa da injustiça: esbanjamento econômico, drama social e holocausto ecológico em Itaipu. 2. ed. Rev. e Ampl. São Paulo: Edições Loyola; Comissão Pastoral da Terra do Paraná, 2003. (Coedição).

MEIRELLES FILHO, João. O livro de ouro da Amazônia. 5. ed. Rio de Janeiro: Ediouro, 2006.

MORIN, Edgar; KERN, Anne Brigitte. Terra-Pátria. Trad. de Amando Pereira da Silva. Lisboa: Instituto Piaget, 1993.

NINIS, Alessandra Bortoni; BILIBIO, Marco Aurélio. Homo sapiens, homo demens e homo degradandis: a psiquê humana e a crise ambiental. Psicologia \& Sociedade, v. 24, n.1, p. 46-55, 2012. Available at 〈http://www.scielo.br/pdf/psoc/v24n1/06.pdf〉. Acess on 28 Sep. 2015. 
ONU/PNUD. Relatório do Desenvolvimento Humano 2013: A ascensão do Sul: progresso humano num mundo diversificado. Portugal: Ministério dos Negócios Estrangeiros; Camões - Instituto da Cooperação e da Língua, 2013. Disponível em:

<http://www.un.cv/files/HDR2013\%20Report\%20Portuguese.pdf>. Acesso em: 10 abr.2015.

PÁDUA, José Augusto. Um sopro de destruição: pensamento político e crítica ambiental no Brasil Escravista (1786-1888). 2. ed. Rio de Janeiro: Jorge Zahar Editor, 2004.

POCHMANN, Cristiano Antônio.; CAROLA, Carlos Renato. Os povos indígenas e o discurso desenvolvimentista retratados no ensino de História do Brasil durante a ditadura militar (1964-1984). Linguagens, Educação e Sociedade: Revista do Programa de Pós-Graduação em Educação da UFPI/Universidade Federal do Piauí/Centro de Ciências da Educação, ano 21, n. 34, 2016, p. 170-198. ISSN 1518-0743. In: http://leg.ufpi.br/ppged/index/pagina/id/1766.

POTSCH, Wlademiro. O Brasil e suas riquezas. 28 ed. Rio de Janeiro: Livraria Francisco Alves, 1956.

POTSCH, Wlademiro. O Brasil e suas riquezas. 32 ed. Rio de Janeiro: Livraria Francisco Alves, 1965. Rio de Janeiro: Fundação Alfredo Herculano Xavier Potsch, 1965.

RIBEIRO, Gustavo Lins. Poder, redes e ideologia no campo do desenvolvimento. Novos Estudos, $\mathrm{n}$. 80, março de 2008, p. 109-125. Available at: http://www.scielo.br/pdf/nec/n80/a08n80.pdf. Access on $02 / 02 / 2017$.

SAUVÉ, Lucie. Uma cartografia das correntes em educação ambiental. In SATO, Michèle, CARVALHO, Isabel (Orgs.). A pesquisa em educação ambiental: cartografias de uma identidade narrativa em formação. Porto Alegre, 2005, p. 17-46.. Available at:

http://web.unifoa.edu.br/portal_ensino/mestrado/mecsma/arquivos/sauve-1.pdf. Access on: 31/01/2017.

VANESKI FILHO, Ener. A construção da usina de Itaipu e o surgimento de atores contrahegemônicos. Revista Paradigma, Ribeirão Preto, ano XVII, n. 21, p. 205-217, jan./dez. 2012. 